\title{
Beta Lactamase Genes of Extended Spectrum Beta Lactamase Producing Escherichia coli from Anorectal Sepsis Cases in Bangladesh
}

\author{
Sheikh Shahidul Islam, Md. Abdul Malek ${ }^{1}$ A K M Fazlul Haque², Kaisar Ali Talukder³, Marufa Zerin Akhter ${ }^{1}$ \\ ${ }^{1}$ Department of Microbiology, University of Dhaka, Dhaka 1000, Bangladesh; ${ }^{2}$ Department of Colorectal Surgery, Bangabandhu Sheikh Mujib \\ Medical University, Dhaka 1000, Bangladesh; ${ }^{3}$ Laboratory of Enteric Microbiology, Laboratory Science Division, International Center for Diarrhoeal \\ Disease Research, Bangladesh (ICDDR,B), Mohakhali, Dhaka 1212, Bangladesh.
}

\begin{abstract}
A microbiological study was carried out to determine the prevalence of extended spectrum beta lactamase (ESBL) producing E. coli in anorectal sepsis patients in Bangladesh. One hundred specimens of pus, swab, or exudates from anorectal sepsis cases were studied. All the 61 isolates of $E$. coli were found to be highly resistant to most of the drugs used. Among these, 14 multidrug resistant E. coli were examined for ESBL production by double disc diffusion method. Six of these were found to be ESBL positive. PCR analysis revealed that 3 of the 6 isolates had coexistence of $b l a_{S H V}$, bla ${ }_{\mathrm{OXA}}$ and $b l a_{\text {СтХM-1 }}$ genes. Two of the isolates had only bla $_{\mathrm{SHV}}$ gene, whereas 1 isolate had a combination of bla $\mathrm{TEM}_{\mathrm{T}}$ and bla $_{\mathrm{SHV}}$ genes. Three of these were resistant to all the drugs tested, while two were sensitive to getamicin and one to ciprofloxacin. None of the E. coli strains possessed bla $_{\text {СтХм-2 }}$, bla ${ }_{\text {СтХм-8 }}, b_{\text {СТХм-9, }}$ and qnr genes.
\end{abstract}

Keywords: extended spectrum beta lactamase (ESBL), Anorectal Sepsis, E .coli, bla ${ }_{\mathrm{SHV}}$, bla $_{\mathrm{TEM}}, \boldsymbol{b l a}_{\mathrm{OXA}}, \boldsymbol{b l a}_{\mathrm{CTXM}-1}$

\section{Introduction}

Many genera of Gram negative bacteria possess a naturally occurring, chromosomally mediated $\beta$-lactamase. Within a few years after its first isolation, $\beta$-lactamase enzymes had spread worldwide and are now found in many different species of the members of the family Enterobacteriaceae as well as Pseudomonas aeruginosa, Haemophilus influenzae, and Neisseria gonorrhoeae ${ }^{1}$. The prevalence of ESBLs among clinical isolates varies from country to country and from institution to institution. In Bangladesh, a study in an urban hospital in Dhaka showed 43.21\% Escherichia coli and 39.4\% Klebsiella pneumoniae as ESBL producers ${ }^{2}$. Numerous outbreaks involving ESBL producing strains have been reported from all over the world making them one of the emerging pathogens. $\beta$-lactamase continues to be a leading cause of resistance to $\beta$-lactam antibiotics among Gram-negative bacteria ${ }^{3}$. Resistant organisms are now worldwide problems. Long term antibiotic exposure, prolonged ICU stay, severe illnesses, nursing home residents, catheterization, or instrumentation are the major risk factor for colonization of ESBL producing bacteria ${ }^{4}$. ESBL producing bacteria can cause both community and hospital acquired infection which can be very difficult to treat with common drugs. Many of the patients infected with ESBL producing bacteria are found in ICU, but they can occur in surgical wards as well as in most other areas of the hospital. ESBL producing bacteria are also being isolated with increasing frequency from patients in extended care facilities ${ }^{5}$.
Anorectal sepsis may be manifested as abscess, fistulae, infected fissure along with injury or surgical wound and may be associated with other pathologies like ulcerative colitis, carcinoma or cancer of the rectum, regional iletis, osteomyelitis of the ischial tubersity, infected pilonidal sinus and pulmonary tuberculosis ${ }^{6}$. The common anorectal pathogens are Proteus spp., Escherichia coli, Pseudomonas spp., Staphylococcus aureus, $\beta$-haemolytic streptococci, Neisseria, and in some cases tuberculous bacilli. As E. coli is the most common opportunistic pathogen as well as the prominent normal flora of the gastrointestinal tract, it has become the point of interest for the researchers worldwide. Very few investigations have been carried out in Bangladesh on bacterial isolates from anorectal sepsis at the molecular level. The present study had been undertaken to explore this area and to find out the prevalence of different ESBL enzymes of $E$. coli from cases of anorectal sepsis in Bangladesh.

\section{Materials and methods}

Sample

125 samples were collected and all of them were subjected to isolation, identification and antibiogram. Pus, exudate swab from different infected wounds or sepsis of the anorectal region of patients with anal abscess, fistulae, post surgical wound (after haemorrhoidectomy, incision and drainage of any origin) and anal fissure were collected aseptically. Multidrug resistant E. coli isolates from cases of anorectal sepsis were assessed. Samples were collected from different hospitals located at Dhaka 
Islam et al.

city, namely, Dhaka Medical College Hospital (DMCH), Bangabandhu Sheikh Mujib Medical University (BSMMU) and Japan Bangladesh Friendship Hospital, Dhaka. The samples were collected from May, 2006 to December, 2007. Majority of the samples were taken from patients who had been admitted in those hospitals and some were collected from the outpatient departments of those hospitals.

\section{Collection of the sample}

Samples were collected aseptically avoiding contamination with commensal microoragnisms or from external sources. For this purpose, few screw capped test tubes were cleaned and sterilized in the autoclave at $121^{\circ} \mathrm{C}$. The samples were obtained by using a sterile cotton swabs and immediately transferred into a sterile screw-capped tube. After collection, the tubes were properly capped, labeled and transferred to the laboratory as soon as possible.

\section{Transportation of the sample}

Delay in the transit of samples to the laboratory was avoided. Special transport medium (thioglycollate broth medium) was used in case of recovery of microorganisms from swabs specimens.
Detection of ESBL producing E. coli by double disc diffusion method

A well-isolated colony of E. coli was inoculated into $2 \mathrm{ml}$ MullerHinton broth and incubated at $37^{\circ} \mathrm{C}$ for $4 \mathrm{~h}$ to obtain a young culture. A Mueller-Hinton agar plate was inoculated, with this suspension using a sterile cotton swab. Discs containing the standard $30 \mu$ g of ceftazidime, ceftriaxone, aztreonam and cefoxitin were placed $15 \mathrm{~mm}$ apart (edge to edge) and from an amoxicillinclavulanic acid disk containing $10 \mu \mathrm{g}$ of the later compound. Following incubation for $16-20 \mathrm{~h}$ at $35^{\circ} \mathrm{C}$, any enhancement of the zone of inhibition between a beta-lactam disk and that containing the beta-lactamase inhibitor was taken as an indication of the presence of an ESBL.

Detection of ESBL encoding genes by PCR assay

The primers and the PCR parameters for detection of the ESBLproducing genes by PCR method are presented in Table 1.

Detection of int1, int 2 and qnr encoding genes by PCR

The primers and the PCR parameters for detection of qnr genes by PCR method are presented in Table 2 .

Table 1. Primers for the detection of ESBL producing genes

\begin{tabular}{|c|c|c|c|c|}
\hline Gene encoding ESBL & Primer & Oligonucleotide sequence (5' to 3') & $\mathrm{T}_{\text {Annealing }}\left({ }^{\circ} \mathrm{C}\right)$ & $\begin{array}{l}\text { Size of amplified } \\
\text { product (bp) }\end{array}$ \\
\hline$\overline{b l a} a_{\mathrm{TEM}}$ & $\begin{array}{l}\text { TEM-F } \\
\text { TEM-R }\end{array}$ & $\begin{array}{l}\text { 5'TCG GGGAAATGTGCGCG3' } \\
\text { 5'TGC TTAATC AGT GAG GAC CC3' }\end{array}$ & 50 & 971 \\
\hline$b l a_{\mathrm{SHV}}$ & $\begin{array}{l}\text { SHV-F } \\
\text { SHV-R }\end{array}$ & $\begin{array}{l}\text { 5'CAC TCA AGG ATG TA TGT G3' } \\
\text { 5'TTA GCG TTG CCAGTG CTCG3' }\end{array}$ & 50 & 885 \\
\hline$b l a_{\mathrm{OXA}}$ & $\begin{array}{l}\text { OXA-F } \\
\text { OXA-R }\end{array}$ & $\begin{array}{l}\text { 5'ACC AGA TTC AAC TTTCAA 3' } \\
\text { 5'TCTT GGC TTTTATGC TTG 3' }\end{array}$ & 55 & 598 \\
\hline$b l a_{\text {СTХ-М-1 }}$ & $\begin{array}{l}\text { CTXM1-F } \\
\text { CTXM1-R }\end{array}$ & $\begin{array}{l}\text { 5'GGACGT ACA GCAAAAACTTGC 3' } \\
\text { 5'CGG TTC GCTTTC ACT TTT CTT 3' }\end{array}$ & 57 & 200 \\
\hline$b l a_{\mathrm{CTX}-\mathrm{M}-2}$ & $\begin{array}{l}\text { CTXM2-F } \\
\text { CTXM2-R }\end{array}$ & $\begin{array}{l}\text { 5'CGG YGC TTAAACAGA GCG AG 3' } \\
\text { 5'CCATGAATAAGCAGC TGATTG CCC } 3^{\prime}\end{array}$ & 59 & 891 \\
\hline$b l a_{\text {СТХ-М-8 }}$ & $\begin{array}{l}\text { CTXM8-F } \\
\text { CTXM8-R }\end{array}$ & $\begin{array}{l}\text { 5'ACG CTC AAC ACC GCG ATC 3' } \\
\text { 5'CGT GGG TTCTCG GGGATA33' }\end{array}$ & 57 & 490 \\
\hline$b l a_{\text {СТХ-М-9 }}$ & $\begin{array}{l}\text { CTXM9-F } \\
\text { CTXM9-R }\end{array}$ & $\begin{array}{l}\text { 5'GAY TGA CCG TATTGG GAG TTT 3' } \\
\text { 5'CGG CTG GGTAAAATA GGTCA3' }\end{array}$ & 57 & 947 \\
\hline
\end{tabular}

Table 2. Primers for the detection of integrons 1, integrons 2 and qnr genes

\begin{tabular}{|c|c|c|c|c|}
\hline $\begin{array}{l}\text { Gene encoding } \\
\text { virulence factor }\end{array}$ & Primer & Oligonucleotide sequence (5' to 3') & $\mathrm{T}_{\text {Annealing }}\left({ }^{\circ} \mathrm{C}\right)$ & $\begin{array}{l}\text { Size of amplified } \\
\text { product (bp) }\end{array}$ \\
\hline \multirow[t]{2}{*}{ int 1} & int $1 F$ & 5'GGCATCCAAGCAGCAAGC 3' & 64 & 1900 and 150 \\
\hline & int $1 R$ & 5'AAGCAAACTTGACCTGAT 3' & & \\
\hline \multirow[t]{3}{*}{ int 2} & int $2 F$ & 5'CGG GAT CCC GGACGG CAT GCACGA & 55 & 220 and 1370 \\
\hline & int $2 R$ & TTT GTA 3' & & \\
\hline & & 5'GAT GCCATC GCAAGTACG AG 3' & & \\
\hline \multirow[t]{2}{*}{$q n r$} & $q n r F$ & 5'GAT AAA GTT TTT CGACAA GAG G 3' & 57 & 593 \\
\hline & $q n r R$ & 5'ATC CAGATCGGCAAAGGTTA3' & & \\
\hline
\end{tabular}




\section{Polymerase chain reaction (PCR)}

Representative isolates were grown overnight on MacConkey agar. A single colony of each isolate was suspended in $25 \mu \mathrm{l}$ of reaction mixer containing $2.5 \mu \mathrm{l}$ of 10x PCR, $1.5 \mu \mathrm{l}$ of $50 \mathrm{mM} \mathrm{MgC1}_{2}$, $2 \mu \mathrm{l}$ of $2.5 \mathrm{mM}$ dNTP, $1 \mu \mathrm{l}$ of primer (forward and reverse) together with 1 unit of Taq DNA polymerase ( $5 \mathrm{U} / \mu \mathrm{l})$. Volume of the reaction mixture was adjusted by adding filtered deionized water. The reaction mixer was overlaid with a drop of mineral oil in order to prevent condensation. PCR assays were performed in a DNA thermal cycler (model 480, Perkin-Elmer Cetus, Emeryville, USA). Each PCR test used the same basic set-up: $96^{\circ} \mathrm{C}$ for $5 \mathrm{~min}$ followed by 23 cycles of $20 \mathrm{sec}$ at $96^{\circ} \mathrm{C}, 20 \mathrm{sec}$ at $\mathrm{T}_{\text {Annealing }}\left({ }^{\circ} \mathrm{C}\right)$ and $\mathrm{Ti}_{\text {Elongate }}$ (min) at $72^{\circ} \mathrm{C}$, with a final extension at $72^{\circ} \mathrm{C}$ for $10 \mathrm{~min}$. A reagent blank, which contained all components of the reaction mixture with the exception of the bacterial template DNA, was included in every PCR procedure. ATCC E. coli (25922) strain was used as the negative control for all PCR. Shigella sonnei K-436 and K438, Shigella sonnei K-548 (1.37 kb) and K-564 (2.00 kb), E. coli 12079, E. coli 192DS2C1, E. coli AD9769C2 and E. coli K-100 were used as positive controls for intl, int2 genes, respectively.
Gel electrophoresis of the PCR products

Amplification products were subjected to horizontal gel electrophoresis in 1\% agarose gel in TBE (Tris-borate EDTA) buffer at room temperature at 100 volt $(50 \mathrm{~mA})$ for $1 \mathrm{~h}$. A $1 \mathrm{~kb}$ and 100 bp DNA size standard (Bio-Rad, USA) was used as a marker to measure the molecular sizes of the amplified products.

\section{Results}

Detection of ESBL producing E. coli by double disc diffusion test.

Amongst the 125 samples, 100 produced bacterial colonies. Out of these 100 isolates, $61 \%$ isolates were identified as E. coli, $22 \%$ were Staphylococcus aureus, $10 \%$ were Proteus and $7 \%$ were found to be Pseudomonas. All the $61 \mathrm{E}$. coli isolates were multidrug resistant. Out of these 61 isolates, 35 were selected on the basis of their origin, type of disease etc. Out of these, 14 were selected for the test of ESBL production by double disc diffusion based on similarities of resistant pattern against a number of antibiotics and area of the specimen sampling.

Out of the 14 multidrug resistant strains tested, 6 were found to be ESBL producing E. coli.

Table 3. Multidrug resistance pattern of the E. coli isolates and screening of ESBL producion by double disc diffusion method (DD)

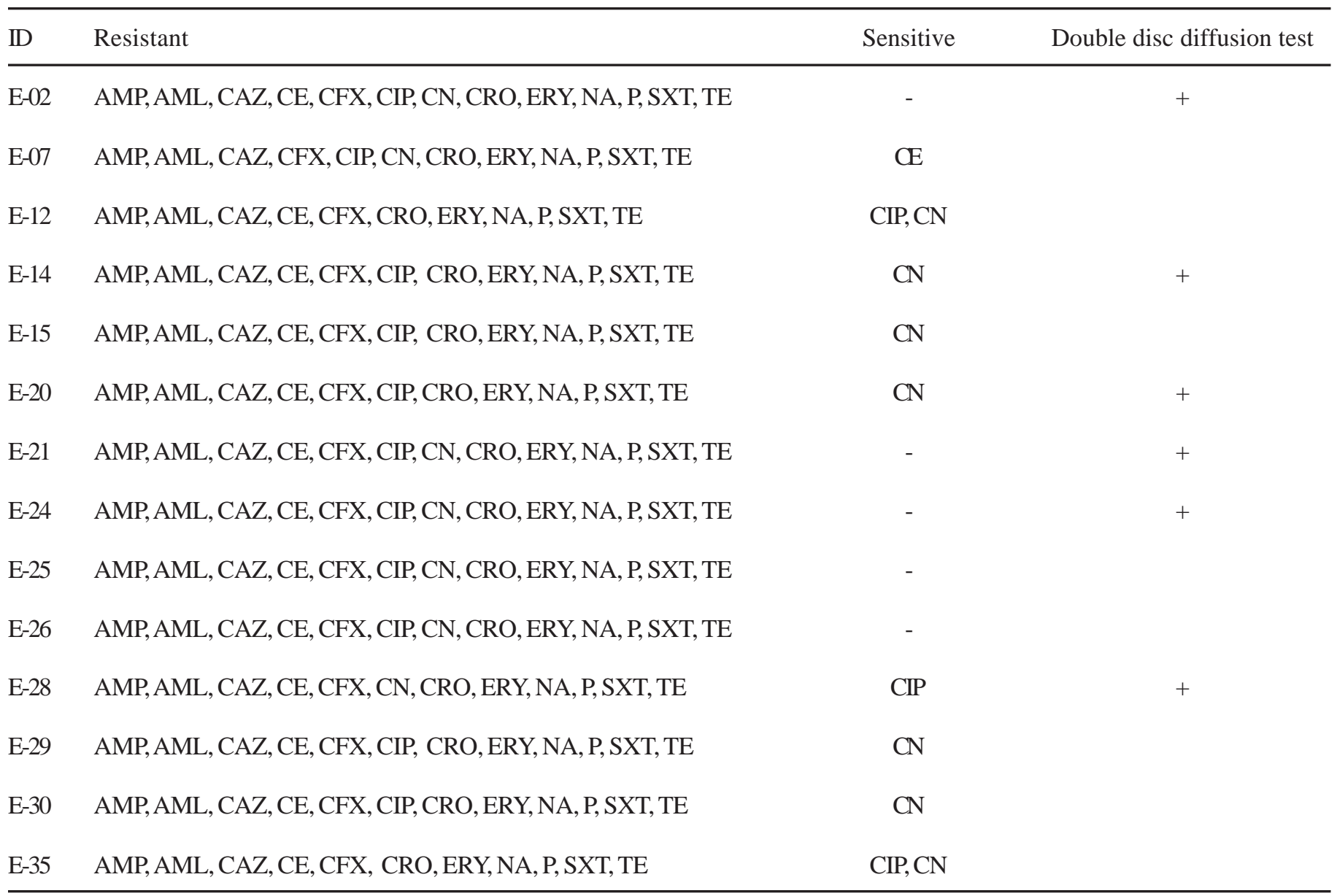

Note: AMP: ampicillin, AML: amoxicillin, CAZ: Ceftazidime, CE: cephradine, CFX: ceftriaxone, CIP: ciprofloxacin, CN: Gentamicin, CRO: Ceftriaxone, ERY: Erythromycin, NA: Nalidixic Acid, P: Penicillin, SXT: Cotrimoxazole, TE: Tetracycline. 


\section{Detection of $\beta$-lactamase-producing genes by PCR}

Isolates with the ESBL phenotypes were examined for the presence of $b l a_{\mathrm{TEM}}, b l a_{\mathrm{SHV}}, b l a_{\mathrm{OXA}}$, and bla $a_{\mathrm{CTX}-\mathrm{M}}$ by PCR. PCR analysis revealed that all the isolates produced either one or more ESBLproducing genes (Figure 1, 2, 3, 4). The $b l a_{\mathrm{TEM}}$, bla $_{\mathrm{SHV}}$, bla $a_{\mathrm{OXA}}$, and $b l a_{\mathrm{CT}-\mathrm{M}-1}$, genes were found to be present alone or together in the ESBL-producing isolates. About $88.88 \%$ E. coli harbored bla $_{\text {SHV }}$ gene and $44.44 \%$ E. coli harbored bla ${ }_{\mathrm{OXA}}$ and bla $a_{\mathrm{CTX}-\mathrm{M}-1}$ genes whereas $22.22 \%$ of $E$. coli contain bla $a_{\text {TEM }}$ gene. None of the isolates was positive for bla $a_{\mathrm{CTX}-\mathrm{M}-2}$, bla ${ }_{\mathrm{CTX}-\mathrm{M}-9}$ and $q n r$ group specific PCR.

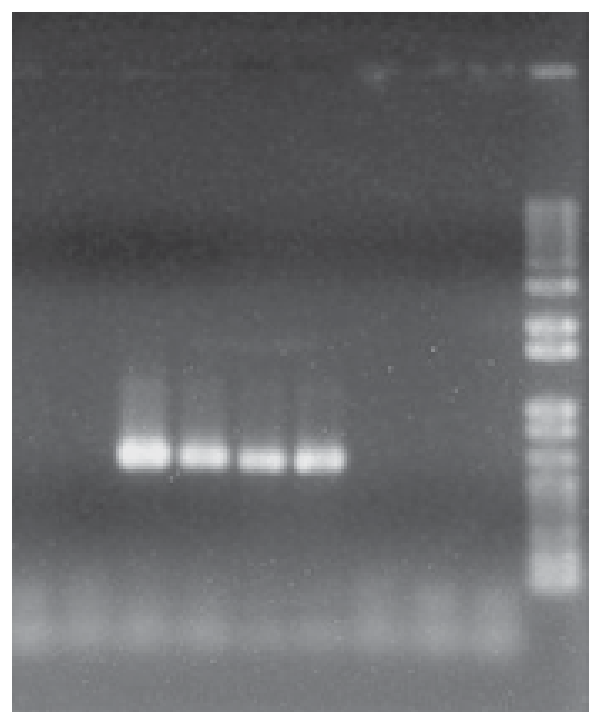

Figure 1. Agarose gel electrophoresis showing $P C R$ amplification products of the bla ${ }_{O X A}(598 \mathrm{bp}$ ) Lane- $A, B, C, D$, representative of $E$. coli $E 14, E 15, E 20, E 25$. Lane-F negative control, Lane-G reagent blank and Lane-H DNA molecular size marker (1 kg DNA ladder from GIBCO-BRL).

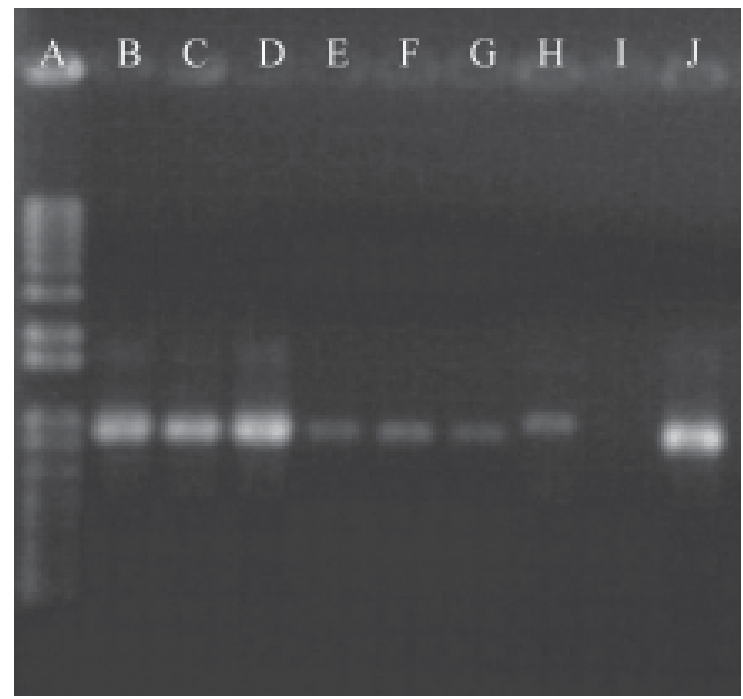

Figure 2. Agarose gel electrophoresis showing PCR amplification products of the bla $a_{S H V}(885 \mathrm{bp})$. Lane $B, C, D, E$, $F, G, H, I, J$ representative of E. coli E02, E07, E12, E14, E20, E21, E24, E26, E28 respectively. Lane A: DNA molecular size marker (1 kb DNA ladder, GIBCO-BRL).

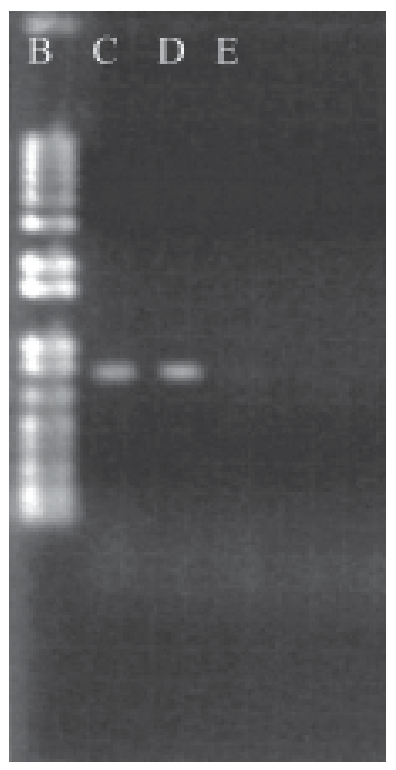

Figure 3. Agarose gel electrophoresis showing PCR amplification products of the bla ${ }_{\text {TEM }}(971 \mathrm{bp})$. Lane $B, C$ representative of $E$. coli $E 02$ and E28 respectively. Lane $A$ represents DNA molecular size marker (1 kb DNA ladder from GIBCO-BRL). Lane D: Negative control (ATCC E. coli 25922).

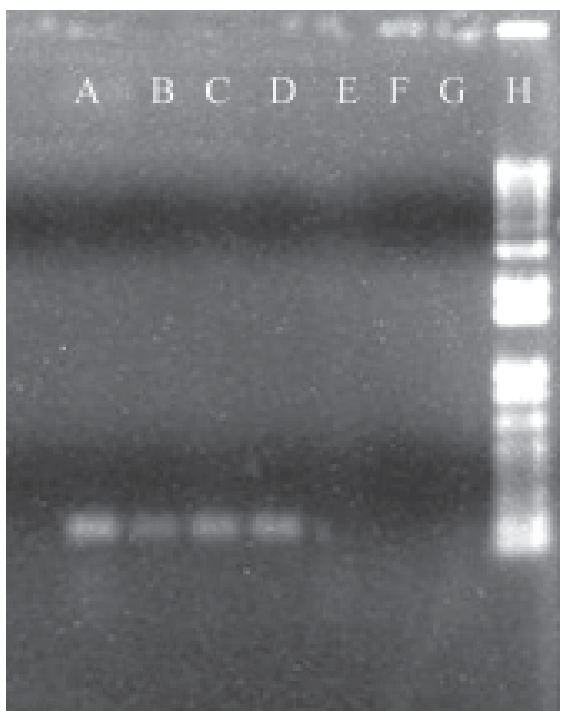

Figure 4. Agarose gel electrophoresis showing PCR amplification products of the bla ${ }_{C T X M-1}(200 \mathrm{bp})$. Lanes $A, B, C$, $D$ : E. coli E-14, E-20, E-21, E-24 respectively. Lane-E neative control (ATCC E. coli 25922), Lane-F: Reagent blank, Lane G: blank, Lane-H DNA molecular size marker (1kb DNA ladder, GIBCO-BRL).

Summarized result of important tests for ESBL producing E. coli

Total 6 isolates were screened for ESBL production, of which 3 isolates were resistant to all drugs tested, 2 isolates were resistant to all drugs except gentamycin and 1 isolate was resistant to all drugs except ciprofloxacin. All the isolates possessed SHV type gene, 3 isolates contained SHV, OXA, and CTX ${ }_{\mathrm{M}-1}$ type gene, whereas, 2 isolates contained only SHV type of gene (Table 3, 4). 
Table-4. Summarized results of pattern of drug resistance and ESBL gene present in E. coli isolates from anorectal sepsis cases.

\begin{tabular}{lll}
\hline $\mathrm{D}$ & Resistant to & Gene present \\
\hline E-02 & AMP, AML, CAZ, CE, CFX, CIP, CN, CRO, ERY, NA, P, SXT, TE & TEM, SHV \\
E-14 & AMP, AML, CAZ, CE, CFX, CIP, $\quad$ CRO, ERY, NA, P, SXT, TE & SHV \\
E-20 & AMP, AML, CAZ, CE, CFX, CIP, CRO, ERY, NA, P, SXT, TE & SHV \\
E-21 & AMP, AML, CAZ, CE, CFX, CIP, CN, CRO, ERY, NA, P, SXT, TE & SHV, OXA, CTX \\
E-24 & AMP, AML, CAZ, CE, CFX, CIP, CN, CRO, ERY, NA, P, SXT, TE & SHV, OXA, CTX \\
E-28 & AMP, AML, CAZ, CE, CFX, CN, CRO, ERY, NA, P, SXT, TE & SHV, OXA, CTX \\
\hline
\end{tabular}

\section{Discussion}

ESBL producing organisms are commonly found in UTI and wound infections. In the present study, the isolates were obtained from various anorectal sepsis cases including surgical wound infections. Over the last two decades many new $\beta$-lactam antibiotics have been developed that were specifically designed to be resistant to the hydrolytic action of $\beta$-lactamases. However, with each new class that has been used to treat patients, new âlactamases emerged that caused resistance to that class of drug.

The production of $\beta$-lactamases is the most relevant resistance mechanism against $\beta$-lactam antimicrobials in Gram-negative organisms. Extended-spectrum $\beta$-lactamases (ESBL) of the TEM, SHV, OXA, and more recently, CTX-M-type enzymes have been described in many countries ${ }^{7}$. Extended-spectrum cephalosporins have been specifically designed to resist degradation by the older broad-spectrum $\beta$-lactamases such as TEM-1, TEM-2, and SHV-1. The response to the extended-spectrum cephalosporins among members of the family Enterobacteriaceae lacking inducible $\beta$-lactamases has been the production of mutant forms of the older $\beta$-lactamases called extended-spectrum $\beta$-lactamases (ESBLs) $^{8}$.

Currently 140 TEM-type enzymes have been described. TEM-10, TEM-12, and TEM-26 are among the most common in the United States ${ }^{9-10}$. More than 60 SHV varieties are known. SHV-5 and SHV-12 are among the most common ${ }^{9}$. More than 80 CTX-M enzymes are currently known. They have mainly been found in strains of Salmonella enterica serovar Typhimurium and E. coli, but have also been described in other species of Enterobactericeae and are the predominant ESBL type in parts of South America. They are also seen in eastern Europe. CTX-M-14, CTX-M-3, and CTX-M-2 are the most widespread. During 2006, CTX-M-15 was the most widespread type in E. coli in the UK and was widely prevalent in the community ${ }^{11}$.

Anorectal sepsis, including wound infections are considered as a serious health problem affecting huge number of people each year. Infections of the anorectal region cause morbidity and mortality all over the world and the worst sufferer are the people of the developing countries like Bangladesh. Surgical treatment including the use of antibiotics and change of lifestyle with altered food habit is the usual treatment of those diseases ${ }^{12}$. Patients of surgical wound are also exposed to great antibiotic pressure ${ }^{13}$. Although there is no systematic report on the ESBLproducers in Bangladesh, a few studies were performed on the prevalence of the ESBL-producing Escherichia coli and Klebsiella pneumoniae that were isolated from Urban Hospital in Dhaka and from some regional medical colleges of Bangladesh that showed $43.2 \%$ E. coli and 39.5\% Klebsiella pneumoniae as ESBL-producers ${ }^{4}$. In addition to the phenotypic characterization, the present study focused particularly on the molecular mechanism of the ESBL- production in E. coli.

Fourteen multidrug resistant $E$. coli isolated from anorectal sepsis cases including wound infection were analyzed for the ESBL-production by double disc diffusion test. Most of these isolates were resistant to all the drugs used. Detection of the ESBL-producing bacteria were done by using $3^{\text {rd }}$ generation cephalosporin ceftazidime, $2^{\text {nd }}$ generation cephalosporin, cefoxitin and aztreonam disc with an augmentin disc (amoxycillin plus clavulanic acid). A previous study carried out by Rahman et al. ${ }^{4}$ reported different rate of isolation of the ESBL in the different combination of $3^{\text {rd }}$ generation cephalosporin (ceftriaxone, cefotaxime, and ceftazidime) discs with augmentin disc. In that study, highest rate of ESBL-positivity was observed with ceftazidime and augmentin combination in $39.5 \%$ of $E$. coli strain. Simultaneous use of four cephalosporin discs with an augmentin disc is recommended in screening for ESBL producing organisms ${ }^{14}$.

Since antibiotic resistance is a major phenotypic trait particularly for the clinical isolates, it has a potential interest in exploring the characteristic of these ESBL-producing isolates of E. coli. In the present study, most ESBL-producers were collected from patients in the surgical ward and from outpatient department. These patients were exposed to great antibiotic pressure. The susceptibility test results showed that all the ESBL-producing isolates were resistant to $3^{\text {rd }}$ generation cephalosporin (ceftriaxone, cefotaxime, and ceftazidime). Increased resistance might be due to the extensive use of the $3^{\text {rd }}$ generation cephalosporins and other â-lactam drugs. All the ESBL-producing isolates were also resistant to $4^{\text {th }}$ generation cephalosporins and monobactams (aztreonam). All the ESBL producing E. coli were resistant to the available antibiotic discs used except one isolate that was found to be sensitive to ciprofloxacin and two isolates that were sensitive to gentamicin. 
Isolates with ESBL phenotypes were examined for the presence of $b l a_{T E M}, b l a_{S H V}, b l a_{O X A}, b l a_{C T X-M}$ genes by PCR. The CTX-M type $\beta$-lactamases represent a rapidly emerging group, which have been found predominantly in Enterobacteriaceae, particularly in E. coli, K. pneumoniae, Proteus mirabilis and Salmonella typhimurium ${ }^{1,15-16}$. In some countries, CTX-M type enzymes are the most frequently isolated ESBLs from E. coli strains ${ }^{17}$. During the 1990s, the CTX-M enzymes became the most common ESBL types in Europe and Argentina ${ }^{18}$. More recently, they have become widespread in Europe and Asia ${ }^{19}$. In recent times, it has been reported that the CTX-M enzymes are the predominant ESBL in most of East Asia ${ }^{20}$. CTX-M-14, CTXM-3, and CTX-M-2 are the most widespread. In 2006, CTX-M-15 was the most widespread type in E. coli the UK and was widely prevalent in the community ${ }^{11}$. However, some reports present TEM to be the predominant one with a percentage of 72.72 and CTX-M as $22.72 \%{ }^{21}$.

In the present study, PCR analysis revealed that 3 out of the 6 isolates had coexistence of $b l a_{\mathrm{SHV}}, b l a_{O X A}$ and $b l a_{\text {CTXM-1 }}$ genes. Two of the isolates had only $b l a_{S H V}$ gene, whereas 1 isolate had a combination of $b l a_{\mathrm{TEM}}$ and $b l a_{\mathrm{SHV}}$ genes. Three of these were resistant to all the drugs tested, while two were sensitive to getamicin and one to ciprofloxacin. None of the E. coli strains possessed $b l a_{\text {СТХм-2 }}$, bla $a_{\text {СТХМ-8 }}$, bla $a_{\text {СтХм-9, }}$ and qnr genes. An interesting observation was that, in all the six ESBL positive isolates $b l a_{\mathrm{SHV}}$ gene was common and 2 out of the 6 isolates tested possessed only bla $a_{\mathrm{SHV}}$ gene that was equally resistant to the other gene combinations observed here. A previous study showed CTX-OXA gene to be present in $26 \%$ of the samples ${ }^{22}$. In the present study, although $50 \%$ of the isolates contained OXA type ESBL gene, it was not the sole ESBL gene present. It was seen in a combination with SHV and CTX-M-1.

In has been seen in many studies throughout the world that combination of beta lactamase genes present in E. coli or other Enterobacteriaceae are diverse. In this study the most prevalent combination was bla $a_{\mathrm{SHV}}$, bla $a_{\text {oxa }}$ and bla $a_{\text {СTХM-1 }}$ together. Although CTX-M-1 has been found in $50 \%$ of the cases, it was in combination with other genes and was not found alone. Some other studies reported to have found CTX-M as the major cause of ESBL production and found alone and not in combination ${ }^{23-25}$. Tangden et al. showed CTX-M-15 to be the prevalent one with some combinations having CTX-M-15, TEM and SHV together ${ }^{26}$. Another study also reported CTX-M to be the major type among MDR E. coli ${ }^{27}$. In a study with Klebsiella sp. Jain et al. showed TEM as the most prevalent one (75\%) and the combination of TEM and SHV type ESBL to be $26.5 \%$. In the present study, one combination among 6 was found to be TEM and SHV type $\operatorname{ESBL}(16.66 \%)^{28}$.

It was previously reported that genes that code for the ESBL are linked to other resistance genes ${ }^{29}$. Moreover, previous fluoroquinolone use has been demonstrated to be a risk factor for the acquisition of the ESBL-producing isolates, particularly isolates producing the CTX-M-type enzymes in the community setting ${ }^{30}$. Yu et al. ${ }^{31}$ described the epidemiology of ciprofloxcin resistance and its relationship to the ESBL production among $K$. pneumoniae strains. An epidemiological link between the ESBL production and ciprofloxacin resistance among Klebsiella spp. was also reported by Brisse et al. ${ }^{32}$. In the present study almost every case of ESBL production was linked to ciprofloxacin resistance.

Presence of $q n r$ gene has been associated with only low-level resistance to fluoroquinolones; however, it can contribute additively to very high levels of resistance associated with chromosomal mutations ${ }^{34}$. Based on phenotypic epidemiological evidences, a significant correlation was found between the ESBLproducers and fluoroquinolone resistance by the work of Wang et al. ${ }^{33}$. However, in the present study, no qnr genes were detected in the ESBL containing E. coli.

The present study was an effort to observe the percentage of ESBL producing $E$. coli from anorectal sepsis cases and also to demonstrate the presence of different ESBL producing genes from these bacteria as well as observing the correlation between the presence of a type of ESBL with the pattern of antibiotic resistance. Due to certain limitations, larger number of samples could not be collected and it was not possible to study all the collected isolates by gene identification. Further studies with more samples from various types of anorectal sepsis are required to effectively correlate the genetic basis of microbial flora involved in the pathogenesis of anorectal sepsis. This study may have reflected some genetic traits of the $E$. coli involved in anorectal sepsis in Bangladesh. The phenotypic and molecular basis of antibiotic resistance, particularly of E. coli, showed in the present study might be of help to the clinicians to develop therapeutic and preventive measures to treat anorectal sepsis.

\section{Refferences}

1. Bradford PA. 2001. Extended-spectrum beta-lactamases in the 21st century: characterization, epidemiology, and detection of this important resistance threat. Clin Microbiol Rev. 14(4): 933-51.

2. Rahman M, Watanabe H, Nair GB and Sack DA. 2004. Genetic relatedness of ciprofloxacin-resistant Shigella dysenteriae type 1 strains isolated in south Asia. J. Antimicrob. Chemother. 54: 730-734.

3. Kliebe C, Nies BA, Meyer JF, Tolxdorff-Neutzling RM \& Wiedemann B. 1985. Evolution of plasmid-coded resistance to broad-spectrum cephalosporins. Antimicrobial Agents and Chemotherapy. 28: 302-7.

4. Chaudhary U and Aggarwal R. 2004. Extended spectrum -lactamases (ESBL) - An emerging threat to clinical therapeutics. Indian J. Med. Microbiol. 22: 75-80.

5. Wiener J, Quinn JP, Bradford PA, et al. 1999. Multiple antibiotic-resistant Klebsiella and Escherichia coli in nursing homes. JAMA. 281: 517: 52 .

6. Russel RC, Norman G, William S and Christopher JK. 2004. In Bailey and Love's Short Practice of Surgery, 24${ }^{\text {th }}$ edn, pp 1263-65. Hodder Arnold, London. 
7. Hernández JR, Martínez-Martínez L, Cantón R, Coque TM \& Pascual A. the Spanish Group for Nosocomial Infections (GEIH). 2005. Nationwide study of Escherichia coli and Klebsiella pneumoniae producing extended-spectrum â-lactamases in Spain. Antimicrob. Agents Chemother. 49: 2122-2125.

8. Pitout JDD, Thomson KS, Hanson ND, Ehrhardt AF, Moland ES and Sanders CC. 1998. $\beta$-lactamases responsible for resistance to extendedspectrum cephalosporins in Klebsiella pneumoniae, Escherichia coli and Proteus mirabilis isolated recovered in South Africa. Antimicrob. Agents Chemother. 42: 1350-1354.

9. Paterson DL, Hujer KM, Hujer AM, Yeiser B, Bonomo MD, Rice LB, Bonomo RA (November 2003). "Extended-spectrum beta-lactamases in Klebsiella pneumoniae bloodstream isolates from seven countries: dominance and widespread prevalence of SHV- and CTX-M-type beta-lactamases”. Antimicrob. Agents Chemother. 47 (11): 355460 .

10. Jacoby GA, Munoz-Price LS (January 2005). The new beta-lactamases. N. Engl. J. Med. 352 (4): 380-91.

11. Woodford N, Ward E, Kaufmann ME, et al.. "Molecular characterisation of Escherichia coli isolates producing CTX-M-15 extended-spectrum $\beta$-lactamase (ESBL) in the United Kingdom”. Health Protection Agency. Retrieved 2006-11-19.

12. Calbo E, Romani V, Xcrcavins M, Gomez L, Vidal CG, Quintana S, Vila J and Garau J. 2006. Risk factors for community-onset urinary tract infections due to Exchcrichia coll harbouring extended-spectrum beta-lactamases. J. Antimicrob. Chemother. 57: 780-783.

13. Eriksson B, Jorup-Ronstrom C, Karkkonen K, Sjoblom AC and Holm SE. 1996. Erysipelas: clinical and bacteriologic spectrum and serologic aspects. Clin. Infect. Dis. 23: 1091-1098.

14. CDC. 1999. Laboratory Detection of Extended Spectrum betalactamases (ESBLs). Available at: http: //www. cdc. gov/ncidod/hip.

15. Bonnet R. 2004. Growing group of extended-spectrum â-lactamases: the CTX-M enzymes. Antimicrob. Agents Chemother. 48: 1-14.

16. Tzouvelekis KS and Bonomo RA. 1999. SHV-type b-lactamases. Curr. Pharm. Des. 5: 847-864.

17. Pitout JDD, Hossain A and Hanson ND. 2004. Phenotypic and Molecular Detection of CTX-M- $\beta$-Lactamases Produced by Escherichia coli and Klebsiella spp. J. Clin. Microbiol. 42(12): 57155721

18. Radice M, Power P and Conza D. 2002. Early dissemination of CTXM-derived enzymes in South America. Antimicrob. Agents Chemother. 46: 602-604.

19. Miro E, Navarro F, Mirelis B. 2002. Prevalence of clinical isolates of Escherichia coli producing inhibitor-resistant inhibitor resistant $\beta$ lactamases at a University Hospital in Barcelona, Spain, over a 3year period. Antimicrobl Agents Chemother. 46: 3991-3994.

20. Munday CJ and Xiong J. 2004. Dissemination of CTX-M type $\beta$ lactamases in Enterobacteriacae isolates in the People's Republic of China. Int. J. Antimicrob. Agents. 23: 175-180.

21. Bali EB, Ac KL, Sultan N. 2010. Phenotypic and molecular characterization of SHV, TEM, CTX-M and extended-spectrumlactamase produced by Escherichia coli, Acinobacter baumannii and
Klebsiella isolates in a Turkish hospital. African Journal of Microbiology Research. 4(8): 650-54.

22. Gomez A, Galic T, Mariet J, Matic I, radman M and Petit M. 2005. Creating New Genes by Plasmid Recombination in Escherichia coli and Bacillus subtilis. Appl. Environ. Microbiol. 71: 7607-09.

23. Hilty M, Betsch BY, Bögli-Stuber K, Heiniger N, Stadler M, Küffer M, Kronenberg A, Rohrer C, Aebi S, Endimiani A, Droz S, Mühlemann K. 2012. Transmission dynamics of extended-spectrumâ-lactamaseproducing Enterobacteriaceae in the tertiary care hospital and the household setting. Clin Infect Dis. 55(7): 967.

24. Sana T, Rami K, Racha B, Fouad D, Marcel A, Hassan M, Sani H, Monzer H. Detection of genes TEM, OXA, SHV and CTX-M in 73 clinical isolates of Escherichia coli producers of extended spectrum Beta-lactamases and determination of their susceptibility to antibiotics.

25. Sharma M, pathak S and Srivastava P. 2013. Prevalence and antibiogram of Extended Spectrum $\beta$-Lactamase (ESBL) producing Gram negative bacilli and further molecular characterization of ESBL producing Escherichia coli and Klebsiella spp. Journal of Clinical and Diagnostic Research 7(10): 2173-2177.

26. Tängdén T, Cars O, Melhus A, Löwdin E. 2010. Foreign travel is a major risk factor for colonization with Escherichia coli producing CTX-M-type extended-spectrum beta-lactamases: a prospective study with Swedish volunteers. Antimicrob. Agents Chemother. 54(9): 3564.

27. Bert F, Larroque B, Paugam-Burtz C, Dondero F, Durand F, Marcon E, Belghiti J, Moreau R, Nicolas-Chanoine MH. 2012. Pretransplant fecal carriage of extended-spectrum $\beta$-lactamase-producing Enterobacteriaceae and infection after liver transplant, France. Emerg. Infect. Dis. 2012. 18(6): 908-16.

28. Jain A and Mondal R. 2008. TEM \& SHV genes in extended spectrum â-lactamase producing Klebsiella species \& their antimicrobial resistance pattern. Indian J Med Res. 128: 759-764.

29. Ahmed I and Salam A. 2002. Extended spectrum $\beta$-lactamases and bacterial resistance. Pak J Med Sci. 18(2):151-55.

30. Valverde A, CoqucTM, Sanchez-Moreno MP, Rollan A, Baquero F and Canton R. 2004. Dramatic increase in prevalence of fecal carriage of extended-spectrum beta-lactamase-producing Enterobacteriaceae during non outbreak situations in Spain. J. Clin. Microbiol. 42: 47694775 .

31. Yu WL, Jones RN, Ilis RJH, Messer SA, Biedenbach DJ, Deshpande LM and Pfaller MA. 2002. Molecular epidemiology of extendedspectrum beta-lactamase-producing, fluoroquinolone-resistant isolates of Klebsiella pneumoniae in Taiwan. J. Clin. Microbiol. 12: 46664669. Taiwan.

32. Brisse S, Milatovic D, Fluit AC, Verhoef J, and Schmitz FJ. 2000. Epidemiology of quinolone resistance of Klebsiella pneumoniae and klebsiella oxytoca in Europe. Eur. J. Clin. Microbiol. Infect. Dis. 19: 64-68.

33. Wang M, Sahm DF, Jacoby GA and Hooper DC. 2004. Emerging plasmid mediated quinolones resistance associated with the qnr gene in Klebsiella pneumoniae clinical isolates in the United States. Antimicrob. Agents Chemother. 48: 1295-1299. 